\title{
Comparison of Two Products of Direct-Fed Microbial Supplementation on the Nutrient Utilization and Ruminal Fermentation in Sheep
}

\author{
Sobhy Mohamed Abdallah Sallam ${ }^{1}$, Ali Mohamed Allam ${ }^{1,2} \&$ Samir Attia Najadi ${ }^{2}$ \\ ${ }^{1}$ Animal Production Department, Faculty of Agriculture, Alexandria University, Egypt \\ ${ }^{2}$ Arid Land Agriculture Department, Faculty of Meteorology, Environment and Arid Land Agriculture, King \\ Abdulaziz University, Jeddah, Saudi Arabia \\ Correspondence: Sobhy Mohamed Abdallah Sallam, Alexandria University, Faculty of Agriculture, Alexandria, \\ El-Shatby 21545, Egypt. Tel: 20-111-100-3962. E-mail: s_sallam@yahoo.com
}

Received: December 31, 2013 Accepted: January 20, 2014 Online Published: February 15, 2014

doi:10.5539/jas.v6n3p159 URL: http://dx.doi.org/10.5539/jas.v6n3p159

\begin{abstract}
This experiment was undertaken to evaluate the potential impacts of supplementing two direct-fed microbial (DFM) products, namely Bactozyme and Ru-max, to the diet of 12 male Barki sheep (live body weight $46.6 \pm 2.9$ $\mathrm{kg}$ ) on dry matter intake (DMI), apparent total tract digestibility of nutrients, nitrogen balance and rumen fermentation characteristics. The Bactozyme or Ru-max were supplemented at a rate of $1.0 \mathrm{~g} / \mathrm{head} / \mathrm{day}$, mixed with the concentrate mixture. Animals were randomly allocated into 3 equal groups $(n=4)$ and were subjected to the digestibility trails.

The results showed that the inclusion of either products of DFM had no positive impact on DMI, but non-significantly improved the apparent total tract digestibility of dry matter (DM), organic matter (OM) and crude protein $(\mathrm{CP})$. However, the Bactozyme addition increased $(\mathrm{P}<0.05)$ the apparent total tract digestibility of neutral detergent fiber (NDF) and acid detergent fiber (ADF). The enhancement of the apparent total tract digestibility of cell wall was not significant for the two of DFM products and a non-significant improvement in cell wall digestion due to the Ru-max supplementation over the control group was found. The DFM products had positive impacts on the average of total digestible nutrients (TDN) and digestible crude protein (DCP) but non significant in comparison with the untreated animals. In addition, the nitrogen balance was improved $(\mathrm{P}>0.05)$ by 8 and 13\% due to Ru-max and Bactozyme supplementation, respectively in comparison with the control group. The results also revealed that inclusion of DFM products had no impacts on rumen $\mathrm{pH} 3.0$ and $6.0 \mathrm{~h}$ after feeding but Bactozyme reduced $(\mathrm{P}<0.05)$ the rumen $\mathrm{pH} 1.0 \mathrm{~h}$ after feeding compared to the control group. The inclusion of Bactozyme and Ru-max increased $(\mathrm{P}>0.05)$ the $\mathrm{NH}_{3}-\mathrm{N}$ concentration in the rumen at 1.0 and $3.0 \mathrm{~h}$ after feeding but the Bactozyme decreased $(\mathrm{P}<0.05)$ the $\mathrm{NH}_{3}-\mathrm{N}$ concentration and increased the volatile fatty acids $(\mathrm{VFA})$ at 6.0 $\mathrm{h}$ after feeding compared to the control group. Overall, results indicated that the two DFM products had positive impacts on cell wall digestibility, which in turn improves metabolic energy supply and nutrients utilization in ruminants as well.
\end{abstract}

Keywords: feed additives, bactozyme, Ru-max, fermentation, nutrients digestibility

\section{Introduction}

Numerous studies have been conducted in an attempt to increase ruminant productivity by manipulating the rumen environment and to increase feed digestibility and nutrient utilization by the animals in order to supply sufficient nutrients to support a high level of milk production. One approach that has recently been widely investigated is the application of direct-fed microbial (DFM) preparations, in order to promote digestion and intestinal hygiene (Gourinier-Chateau et al., 1994), enhance animal performance and reduce usage of antibiotics (Jouany \& Morgavi, 2007; Guedes et al., 2008; Wallace et al., 2008).

The definition of DFM is very broad and may include specific and nonspecific yeast, fungi, bacteria, cell fragments, and filtrates (Knowlton et al., 2002). The supplementation of DFM agents in dairy rations has become a generally accepted practice with the following stated benefits: increased ruminal digestion, dry matter intake (DMI), and milk production and reduced body temperature (Piva et al., 1993; Higginbotham et al., 1994; McGilliard \& Stallings, 1998). Enterococcus faecium produces moderate amounts of lactic acid in the rumen. This could stimulate growth of lactic acid utilizer's micrororganisms and stabilize ruminal $\mathrm{pH}$ (Nocek et al., 2002; 
2003). Yeast and yeast products have been widely used in ruminant nutrition to manipulate rumen fermentation and improve animal performance (Bruno et al., 2009; Yalçin et al., 2011). In addition, other studies have shown substantial improvement of feed digestibility, rumen fermentation and animal performance due to fibrolytic enzymes supplementation (Bala et al., 2009; Gado et al., 2009; Holtshausen et al., 2011).

However, testing DFM supplementation produced variable and inconsistent results so far (cf. also Z. Mir \& P. S. Mir, 1994). One main point to explain this is the diversity of DFM origin. Several biotic factors such as the strain of yeast, bacteria, fungi, enzymes and its viability, nature of the diet, animal type and its physiological status and level of performance may play considerable role in this regard. Still, direct comparisons among direct-fed microbial products have rarely been carried out, and a comprehensive analysis of variables indicative of the complex of influence of such products is mostly lacking. Therefore, the present study was conducted to compare the responses of Barki sheep to supplementation of two commercial DFM and determine their effect on feed intake, nutrients digestibility, nitrogen $(\mathrm{N})$ utilization and rumen fermentation characteristics.

\section{Materials and Methods}

This experiment was conducted at the Milk Production Project, Animal Production Department, Faculty of Agriculture, Alexandria University, Egypt. All analyses were carried out at the Animal Nutrition Laboratory, Department of Animal Production, Faculty of Agriculture, Alexandria University, Egypt.

\subsection{Animals and Management}

Twelve adult male Barki sheep (live body weight, $46.6 \pm 2.9 \mathrm{~kg}$ ), a small Egyptian fat-tailed sheep breed, were randomly allocated to equal three groups $(\mathrm{n}=4)$. The control group received a basal diet, which composed concentrate mixture and Egyptian clover (Alexandrium trifolum) hay without supplement, the other two groups received the basal diet plus either $1.0 \mathrm{~g}$ of Ru-max/head/day or $1.0 \mathrm{~g}$ of Bactozyme /head/day according to the producer recommendations. The DFM product Ru-max ${ }^{\circledR}$ (Agri-King, Inc., Fulton, USA) is composed from cellulases, $\beta$-glucanases, amlyases, Aspergillus oryzae, Enterococcus faecium and Saccharomyces Cerevisiae. Bactozyme is a microbial feed additive (Dyno Vet. Company, the Egyptian - French Factory, Alexandria, Egypt) consisting of Saccharomyces cerevisiae $\left(20 \times 10^{10} \mathrm{CFU}\right)$, total live bacteria $\left(2 \times 10^{10} \mathrm{CFU}\right)$, Lactobacillus acidophilus $\left(2 \times 10^{9} \mathrm{CFU}\right)$, Lactobacillus casei $\left(0.4 \times 10^{8} \mathrm{CFU}\right)$, Lactobacillus plantarum $\left(1.6 \times 10^{9} \mathrm{CFU}\right)$,

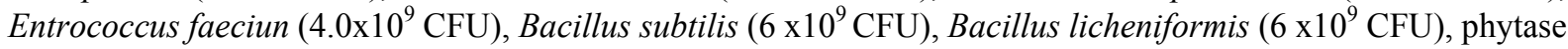
(2400 U), lipase (2400 U), xylanase (1200 U), cellulase (2400 U), pectinase $400 \mathrm{U}$, amylase (20000 U), protease (40000 U), $\beta$-gluconase (1000 U), fructo oligosaccharides (10 g), mannan oligosaccharides (10 g), calcium propionate $(24 \mathrm{~g})$, copper penta sulphate $(10 \mathrm{~g})$ and carrier up to $1 \mathrm{~kg}$.

The animals were housed individually in metabolic crates under a protective roof and had free access to fresh water throughout the study. The basal diet consisted of clover hay and a concentrate mixture the composition of which is given in Table 2. The diet components were offered twice daily at $08: 00$ and 16:00 h in amounts of 750 and $750 \mathrm{~g}$ as fed/day foreach of clover hay and concentrate mixture, respectively. The experimental period lasted for 30 days, with the first 21 days being an adaptation period to the diet, followed by 7 days of sample collection (feces, urine, refusal feed). Individual intakes of clover hay and concentrate were recorded daily by weighing the feed offered and refused. During the collection period, also the complete output of feces was recorded by collection in buckets. Feces samples of $100 \mathrm{~g} / \mathrm{kg}$ of total weight were collected and stored under $5^{\circ} \mathrm{C}$ during the collection period. Directly afterwards, the samples collected during the 7 days were mixed. One kilogram of this mixture was dried at $60^{\circ} \mathrm{C}$ for $72 \mathrm{~h}$ in a forced air oven, ground through a $1-\mathrm{mm}$ screen and stored at room temperature until analysis. The remainder was kept in a freezer $\left(-20^{\circ} \mathrm{C}\right)$ for analysis of dry matter $(\mathrm{DM})$ and total $\mathrm{N}$. The urine was completely collected in plastic buckets containing $100 \mathrm{ml}$ of $\mathrm{H}_{2} \mathrm{SO}_{4}(10 \%)$, and the amounts were recorded and samples (10\%) were collected daily. These samples were stored in a freezer $\left(-20^{\circ} \mathrm{C}\right)$ during the collection period. Just after the collection period, the urine samples were pooled per animal and representative samples were frozen at $-20^{\circ} \mathrm{C}$ until further analysis.

The ruminal fluid was collected via the stomach tube at 1.0,3.0 and $6.0 \mathrm{~h}$ after feeding consecutive for consecutive 2 days. The rumen $\mathrm{pH}$ was measured immediately after collection using $\mathrm{pH}$ meter. The rumen fluid was separated from the feed particles through four layers of gauze and stored at $-20^{\circ} \mathrm{C}$ for later analysis.

\subsection{Sample Analyses}

Chemical analyses were performed according to AOAC (2006). DM contents of feeds and refusals were determined by drying at $135^{\circ} \mathrm{C}$ for $2 \mathrm{~h}$, but of feces were dried at $105^{\circ} \mathrm{C}$ overnight. OM was determined as the weight loss after ashing at $550^{\circ} \mathrm{C}$ for $2 \mathrm{~h} . \mathrm{N}$ content of feeds, feces and acidified urine was determined using the Kjeldahl method, and CP was calculated as $6.25 \times \mathrm{N}$. Ether extract (EE) was analyzed according to AOAC (2006). 
Neutral detergent fiber (NDF) and acid detergent fiber (ADF) were determined using the procedures of Van Soest et al. (1991). No sodium sulfite and $\alpha$-amylase were used in the procedure for NDF determination. Both NDF and ADF are expressed without residual ash. Concentrations of $\mathrm{NH}_{3}-\mathrm{N}$ and total volatile fatty acids (VFA) in rumen fluid were determined by distillation using Markham apparatus according to the Preston (1995) and Warner (1964), respectively.

\subsection{Statistical Analysis}

Data were analyzed using the generalized linear model procedure (SAS, 2002). The following model was assumed: $Y_{i j}=\mu+T_{i}+e_{i j}$ where: $\mu$ is the overall mean, $T_{i}$ is the treatment type, $e_{i j}$ is the random error term. Differences among means were tested using Duncan multiple range test (Steel \& Torrie, 1980).

\section{Results}

The mean values of the proximate analysis on DM basis of the concentrate mixture and clover hay are presented in Table 1. The results of the proximate analysis showed that $\mathrm{OM}, \mathrm{CP}$ and $\mathrm{EE}$ of concentrate mixture and clover hay were 895 vs. 890,142 vs. 135 and 38.6 vs. $14 \mathrm{~g} / \mathrm{kg}$, respectively, while, NDF, ADF and hemicellulose content of the concentrate mixture were 398, 176 and 222, respectively and were 448, 282 and $166 \mathrm{~g} / \mathrm{kg}$ for Egyptian clover, respectively.

Table 1. Ingredients and chemical composition of concentrate mixture and clover hay fed to Barki sheep

\begin{tabular}{|c|c|c|}
\hline \multirow{2}{*}{$\begin{array}{l}\text { Ingredients, } \\
\text { Ground yellow corn }\end{array}$} & \multicolumn{2}{|c|}{$\mathrm{g} / \mathrm{kg} \mathrm{DM}$} \\
\hline & \multicolumn{2}{|c|}{250} \\
\hline Wheat bran & \multicolumn{2}{|c|}{300} \\
\hline Cotton seed meal & \multicolumn{2}{|c|}{170} \\
\hline Sunflower meal & \multicolumn{2}{|c|}{245} \\
\hline Limestone & \multicolumn{2}{|c|}{20.0} \\
\hline Sodium chloride & \multicolumn{2}{|c|}{10.0} \\
\hline Trace minerals* & \multicolumn{2}{|c|}{5.0} \\
\hline Items (g/kg DM) & Concentrate mixture & Clover hay \\
\hline OM & 895 & 890 \\
\hline $\mathrm{CP}$ & 142 & 135 \\
\hline $\mathrm{EE}$ & 38.6 & 014 \\
\hline NDF & 398 & 448 \\
\hline $\mathrm{ADF}$ & 176 & 282 \\
\hline Hemicellulose & 222 & 166 \\
\hline
\end{tabular}

*Mineral mixture contained (g/kg): Manganese Sulphate12.58, Zinc Sulphate 9.3, Copper Sulphate 3.2, Ferrous sulphate 16.67 Calcium iodate 0.081, Sodium selenite 0.4, Magnesium oxide 9.4, Cobalt sulphate 0.2, Sodium chloride Add to $\mathrm{kg}(\mathrm{M} / \mathrm{s}$, Dyno vet company, Alexandria, Egypt).

Data of feed intake, nutrients apparent total tract digestibility and feeding values of rations without (control) or with Bactozyme and Ru-max are summarized in Table 2. The results showed that the inclusion of two products of DFM had no positive impact on DMI compared to the control group. The ratios of consumed clover hay and concentrate were 44.3:55.7; 44.0:56.0 and 43.3:56.7\% for the control, Ru-maz and baztozyme groups, respectively. However, the supplementation of Bactozyme or Ru-max apparently improved the apparent total tract digestibility of DM, OM and CP but the improvement was not significant compared to the control. While the Bactozyme addition increased $(\mathrm{P}<0.05)$ the apparent total tract digestibility of NDF and ADF significantly, Ru-max only showed numerical increases compared to the control group. Although, DFM had positive responses on the mean values of TDN and DCP, no significant changes in comparison to the untreated animals were observed. 
Table 2. Effects of Bactozyme and Ru-max supplementation on dry matter intake (DMI), nutrients apparent total tract digestibility and nutritive value in Braki sheep (Means \pm SE)

\begin{tabular}{lccc}
\hline & Control & Ru-Max & Bactozyme \\
\hline DMI, g/head/d & $1158.9 \pm 19.5$ & $1154.4 \pm 19.5$ & $1165.8 \pm 19.5$ \\
\hline \multicolumn{4}{l}{ Apparent total tract digestibility, $\%$} \\
\hline Dry matter & $66.9 \pm 1.3$ & $68.1 \pm 1.3$ & $69.9 \pm 1.3$ \\
Organic matter & $67.3 \pm 1.3$ & $68.4 \pm 1.3$ & $70.6 \pm 1.3$ \\
Crude protein & $71.5 \pm 1.2$ & $72.5 \pm 1.2$ & $74.3 \pm 1.2$ \\
Ether extract & $75.2 \pm 1.3^{\mathrm{b}}$ & $81.4 \pm 1.3^{\mathrm{a}}$ & $78.7 \pm 1.3^{\mathrm{ab}}$ \\
Neutral detergent fiber & $58.8 \pm 1.3^{\mathrm{b}}$ & $61.1 \pm 1.3^{\mathrm{ab}}$ & $63.2 \pm 1.3^{\mathrm{a}}$ \\
Acid detergent fiber & $40.6 \pm 2.3^{\mathrm{b}}$ & $45.4 \pm 2.0^{\mathrm{ab}}$ & $49.3 \pm 2.2^{\mathrm{a}}$ \\
TDN & $63.3 \pm 1.5$ & $64.7 \pm 1.5$ & $68.0 \pm 1.5$ \\
DCP & $10.0 \pm 0.16$ & $10.2 \pm 0.16$ & $10.6 \pm 0.16$ \\
\hline
\end{tabular}

Different letters $(a, b)$ in the same row indicate significant differences $(\mathrm{P}<0.05)$.

TDN: Total digestible nutrients; DCP: Digestible crude protein.

The effects of Bactozyme and Ru-max supplementation on $\mathrm{N}$ utilization are given in Table 3. Fecal and urinary $\mathrm{N}$ decreased ( $\mathrm{P}>0.05)$ when Bactozyme and Ru-Max were supplemented compared to the control group. In addition, the $\mathrm{N}$ balance was apparently improved $(\mathrm{P}>0.05)$ by 8 and $13 \%$ due to $\mathrm{Ru}-\mathrm{max}$ and Bactozyme supplementation, respectively in comparison to the control group.

Table 3. Effect of Bactozyme and Ru-max supplementation on nitrogen fractions of Barki sheep (Means \pm SE)

\begin{tabular}{llll}
\hline & Control & Ru-Max & Bactozyme \\
\hline N intake, g/d & $25.8 \pm 0.53$ & $25.7 \pm 0.53$ & $25.9 \pm 0.53$ \\
Fecal N, g/d & $7.4 \pm 0.67$ & $6.9 \pm 0.67$ & $6.1 \pm 0.67$ \\
Urinary N, g/d & $9.2 \pm 1.47$ & $7.9 \pm 1.47$ & $8.7 \pm 1.47$ \\
Nitrogen balance, g/d & $9.2 \pm 1.34$ & $10.9 \pm 1.34$ & $11.1 \pm 1.34$ \\
\hline
\end{tabular}

Mean values of rumen $\mathrm{pH}$ revealed that Bactozyme inclusion reduced $(\mathrm{P}<0.05)$ rumen $\mathrm{pH}$ after $1.0 \mathrm{~h}$ of feeding but, $\mathrm{pH}$ at subsequent intervals such as 3.0 and $6.0 \mathrm{~h}$ after feeding were statistically comparable with control.

Table 4. Effect of Bactozyme and Ru-max supplementation on rumen $\mathrm{pH}$ after different times at morning feeding of Barki sheep

\begin{tabular}{lccc}
\hline \multirow{2}{*}{ Groups } & \multicolumn{3}{c}{ Rumen $\mathrm{pH}$} \\
\cline { 2 - 4 } & $1.0 \mathrm{~h}$ & $3.0 \mathrm{~h}$ & $6.0 \mathrm{~h}$ \\
\hline Control & $6.43 \pm 0.07^{\mathrm{a}}$ & $6.49 \pm 0.07$ & $6.62 \pm 0.09$ \\
Ru-max & $6.40 \pm 0.07^{\mathrm{ab}}$ & $6.47 \pm 0.07$ & $6.67 \pm 0.09$ \\
Bactozyme & $6.21 \pm 0.07^{\mathrm{b}}$ & $6.28 \pm 0.07$ & $6.52 \pm 0.09$
\end{tabular}

Different letters $(a, b)$ in the same column indicate significant differences $(\mathrm{P}<0.05)$.

Bactozyme and Ru-max supplementation showed apparent increase $(\mathrm{P}>0.05)$ in the $\mathrm{NH}_{3}-\mathrm{N}$ at 1.0 and $3.0 \mathrm{~h}$ of post feeding. However, it was higher on Ru-max at $6.0 \mathrm{~h}$ of post feeding $(\mathrm{P}<0.05)$ than Bactozyme and comparable to control. Bactozyme and Ru-max supplementation had no effects on VFA concentration either 1.0 or $3.0 \mathrm{~h}$ after feeding but VFA concentration was increased $(\mathrm{P}<0.05)$ on both supplements compared to control. 
Table 5. Effect of Bactozyme and Ru-max supplementation on $\mathrm{NH}_{3}-\mathrm{N}$ concentration after different times at morning feeding of Barki sheep

\begin{tabular}{lccc}
\hline \multirow{2}{*}{ Groups } & \multicolumn{3}{c}{$\mathrm{NH}_{3}-\mathrm{N}(\mathrm{mg} / \mathrm{dL})$ concentration } \\
\cline { 2 - 4 } & $1.0 \mathrm{~h}$ & $3.0 \mathrm{~h}$ & $6.0 \mathrm{~h}$ \\
\hline Control & $15.5 \pm 2.0$ & $19.4 \pm 1.88$ & $19.9 \pm 1.7^{\mathrm{ab}}$ \\
Ru-max & $18.7 \pm 2.1$ & $21.4 \pm 2.4$ & $20.8 \pm 1.5^{\mathrm{a}}$ \\
Bactozyme & $19.4 \pm 2.1$ & $20.1 \pm 2.1$ & $16.3 \pm 1.8^{\mathrm{b}}$ \\
\hline
\end{tabular}

Different letters $(a, b)$ in the same column indicate significant differences $(\mathrm{P}<0.05)$.

Table 6. Effect of two products of direct-fed microbial supplementation on VFA concentration after different times at morning feeding in Barki sheep

\begin{tabular}{lccc}
\hline & \multicolumn{3}{c}{ VFA concentration $(\mathrm{meq} / \mathrm{dL})$} \\
\cline { 2 - 4 } & $1 \mathrm{~h}$ & $3 \mathrm{~h}$ & $6 \mathrm{~h}$ \\
\hline Control & $10.51 \pm 0.69$ & $8.73 \pm 0.80$ & $7.25 \pm 0.41^{\mathrm{b}}$ \\
Ru-max & $10.85 \pm 0.69$ & $8.61 \pm 0.81$ & $10.09 \pm 0.61^{\mathrm{a}}$ \\
Bactozyme & $9.59 \pm 0.76$ & $9.09 \pm 0.80$ & $9.18 \pm 0.55^{\mathrm{a}}$ \\
\hline
\end{tabular}

Different letters $(\mathrm{a}, \mathrm{b})$ in the same row indicate significant differences $(\mathrm{P}<0.05)$.

\section{Discussion}

Cellulose and hemicellulose represent about $250-300 \mathrm{~g} / \mathrm{kg}$ of most ruminant diets. These plant cell wall polymers are insoluble, structurally complex and not totally physically accessible, which explains why their degradation is sometimes limited. Moreover, the host enzymes are unable to hydrolyze these kinds of molecules. Improving the bioavailability of nutrients in a feedstuff by increasing the cell wall hydrolysis through the microbial supplement is a promising solution and, DFM preparations are reported to promote digestion and intestinal hygiene (Gourinier-Chateau et al., 1994), enhance animal performance and reduce usage of antibiotics (Jouany \& Morgavi, 2007; Guedes et al., 2008; Wallace et al., 2008).

Ru-max and Bactozyme supplementation did not improve DMI and digestibility of DM, OM and CP but, digestibility of EE, NDF and ADF were improved significantly. Dawson (1992) also reported that the addition of DFM resulted in increased concentration of total anaerobic bacteria and the increase was associated with fibre digesting and lactic acid utilizing bacteria (Dawson 1992). The components that are used in DFM may be classified as lactic acid utilizing bacteria Enterococcus, (LUB), yeast products containing Saccharomyces cerevisiae and fungi Aspergillus oryzae, fibrolytic enzymes and cobalt carbonate. The LUB potentially moderatesrumen conditions and improve feed efficiency. Yeast DFM may reduce harmful oxygen, prevent excess lactate production, increase feed digestibility, and improve fermentation in the rumen. The DFM may also compete with and consequently inhibit the growth of pathogens, stimulate immune function, and modulate microbial balance in the gastrointestinal tract.

Many workers reported that the supplementation of DFM in ruminant rations has become a generally accepted practice due to increased ruminal digestion, DMI, performance and reduced body temperature (Piva et al., 1993; Higginbotham et al., 1994; McGilliard \& Stallings, 1998). Nikkhah et al. (2004) and Raeth-Knight et al. (2007) have observed non-significant improvement of DMI by animals fed with yeast culture. Similalry, Bernard et al. (2010) and Arriola et al. (2011) reported that adding fibrolytic enzymes supplementation to dairy cow diet did not enhance DMI and no difference was found between cows supplemented with or without fibrolytic enzymes. DMI is often considered as a function of the initial rate of fiber digestion. An early stimulation of ruminal activity can be expected to have a major impact on the feed consumption and can provide a driving force for improved animal performance. Although significant improvement in the NDF digestibility was observed with Ru-max and Bactozyme supplementation, it could be presumed that they might be lagging in improving the initial rate of fiber digestion that could be translated into enhanced DMI. Supplementing lactating dairy cows with DFM products containing Lactobacillus acidophilus and Propionibacterium freudenreichii did not affect rumen fermentation in cows. On the other hand, Szasz, (2002), Ware and Zinn (2005) reported that Fibrozyme inclusion to the steers or heifer's diets increased total tract digestibility of NDF and ADF and increased DMI and average daily gain. Few 
workers concluded improved feed intake, feed conversion rate, daily weight gain and total body weight in sheep, goat and cattle on administration of DFM (Torres-Rodriguez et al., 2007; Samli et al., 2007; Casey et al., 2007). Improvement from DFM supplementation could be anticipated due to positive effects on various digestive processes, especially cellulolysis, synthesis of microbial protein, stabilizers of ruminal $\mathrm{pH}$ and lactate, increased absorption of some nutrients and displayed a growth-promoting effect. The positive effect of the Bactozyme additive on NDF digestibility in this study might be related to stimulation of growth of cellulolytic bacteria. However, the effects of DFM on DMI appeared varying in this study probably due to variation in products, methods of applying, roughage: concentrate ratio (Yang et al., 2000; Bowman et al., 2002).

No increase in CP digestibility was observed in confirmation to Bassiouni et al. (2010) who supplemented fibrozyme to corn silage or rice straw. Mean values of DM and OM apparent total tract digestibility were not affected, while apparent total tract digestibility of NDF and ADF were improved $(\mathrm{P}<0.05)$ in treated groups compared to the control group. These results were in accordance with Beauchemin et al. (2003) and Arriola et al. (2011) who reported that exogenous enzymes improve apparent total tract digestibility of plant cell wall, and there is evidence for numerous potential modes of action suggesting their interdependence. Adding Bactozyme and Ru-max to a diet may increase the hydrolytic capacity of the rumen mainly due to increased bacterial attachment, stimulation of rumen microbial populations and synergistic effects with hydrolases of ruminal microorganisms. The net effect is increased enzymatic activity within the rumen, which enhances digestibility of the feed. Moreover, DFM supplementation to ruminant diets could also partly reduce digesta viscosity (Hristov et al., 2000) and alter ruminal fermentation (Gado et al., 2009; Arriola et al., 2011) and/or enhance attachment and colonization to the plant cell wall by ruminal microorganisms (Wang et al., 2001, Holtshausen et al., 2011) by synergism with enzymes or stimulate the rumen microbial numbers.

The TDN and DCP were not significantly changed between treatments as observed by Ismaiel et al. (2010). An apparent trend in improved $\mathrm{N}$ balance on study due to DFM supplementation was observed that was due to less of excretion of urinary nitrogen and fecal nitrogen in sheep fed bactozyme and Ru-max compared with control group, which in consistent with observations reported by El-Ashry et al. (2003); Ahmed and Salah (2006) and Ismaiel et al. (2010).

DFM feeding showed variable and inconsistent affect on altering rumen fermentation patterns. Some reports have demonstrated no effects of yeast culture supplementation on ruminal $\mathrm{pH}$, rumen ammonia concentration, and VFA patterns in vivo (Wiedmeier et al., 1987) and in vitro (Newbold et al., 1996). Microbial conversion of peptides and amino acids to ammonia in the rumen is unfavourable to the host animal, because energy is required for microbial protein synthesis, and not all ammonia is incorporated into protein (Wallace et al., 1997). Consequently, if high levels of ammonia occur in the rumen, a large amount of $\mathrm{N}$ is excreted in urine and feces. For example, in animal production systems feeding high amounts of $\mathrm{N}$, more than half of it is excreted in urine, mostly in the form of urea which is rapidly mineralised in $\mathrm{NH}_{3} / \mathrm{NH}_{4}+$ and then converted to nitrous oxide $\left(\mathrm{N}_{2} \mathrm{O}\right)$, which has a global warming potential that is 296 fold that of carbon dioxide $\left(\mathrm{CO}_{2}\right)$ and more than 12 fold that of methane (Steinfeld et al., 2006). Because of the increasing concern of the role of livestock on climate change, nutritional strategies that aim at decreasing $\mathrm{N}$ loss in the rumen are of interest.

A decrease in $\mathrm{NH}_{3}$ concentration is attributed to ruminal microbial proliferation, due to the increase of microbial use of available $\mathrm{NH}_{3}$ for microbial $\mathrm{N}$ synthesis (Crocker et al., 1998). Some of the DFM e.g. galacto-oligosaccharides, are known to suppress ammonia producing bacteria, and stimulate the production of Bifidobactrium, which has the ability to assimilate ammonia as a N source (Deguchi et al., 1993). Beauchemin et al (2000) found that enzyme supplementation decreased $\mathrm{NH}_{3} \mathrm{~N}$ value before and after feeding. This decreasing in $\mathrm{NH}_{3} \mathrm{~N}$ was likely caused by an increase in ruminal availability of slowly digestible carbohydrates due to enzyme supplementation.

Nutrients of forage cell walls are degraded to several metabolites, such as VFA, by ruminal bacteria, protozoa, and fungi. Results clearly indicated that no significant effect on VFA's concentration by Bactozyme or Ru-max supplementation at 1 or $3 \mathrm{~h}$ after feeding but the VFA increased significantly at $6 \mathrm{~h}$ after feeding compared to the control group. This result was associated with Kung et al. (2002); Sutton et al. (2003); Eun and Beauchemin (2005) who concluded that total VFA were not affected by enzyme supplementation, while Arriola et al. (2011) reported that fibrolytic enzymes supplementation increased $(\mathrm{P}<0.03)$ VFA concentration. However, the animal responses to DFM addition have been highly variable, apparently influenced by the composition of the diet and much remains to be elucidated about the dose- and diet-dependence of DFM effects (Chaucheyras-Durand et al., 2008). The variations among these studies may be due to differences in roughage: concentrate ratio, which may have effects on lactic acid concentration and rumen $\mathrm{pH}$. 


\section{Conclusions}

In conclusion, under the conditions of this study, both types of the investigated DFM (Ru-max and baztozyme) had no positive impacts on DMI, N utilization but improved cell wall digestibility as one of the key targets of the DFM products supplementation, which then would improve metabolic energy supply and nutrients utilization in ruminants as well.

\section{References}

Ahmed, B. M., \& Salah, M. S. (2006). Effect of yeast culture as an additive to sheep feed on performance, digestibility, nitrogen balance and rumen fermentation. J. Agri. Sci., 1(14), 1-13. http://dx.doi.org/10.3168/jds.2010-3424

AOAC. (2006). Official Methods of Analysis of AOAC International (2000, 20th ed.). AOAC International, Arlington, VA, USA. http://dx.doi.org/10.1111/j.1740-0929.2009.00634.x

Arriola, K. G., Kim, S. C., Staples, C. R., \& Adesogan, A. T. (2011). Effect of fibrolytic enzyme application to low and high concentrate diets on the performance of lactating dairy cattle. J. Dairy Sci., 94, 832-841.

Bala, P., Malik, R., \& Srinivas, B. (2009). Effect of fortifying concentrate supplement with fibrolytic enzymes on nutrient utilization, milk yield and composition in lactating goats. J. Anim. Sci., 80, 265-272.

Bassiouni, M. I., Gaafar, H. M. A., Mohi El-Din, A. M. A., Metwally, A. M., \& Elshora, M. A. H. (2010). Evaluation for rations supplemented with fibrolytic enzyme on dairy cows performance 3. Productive performance of lactating Friesian cows. Livestock research for rural development, 22(6).

Beauchemin, K. A., Colombatto, D., Morgavi, D. P., \& Yang, W. Z. (2003). Use of exogenous fibrolytic enzymes to improve feed utilization by ruminants. J. Amin. Sci., 81 (E. Suppl. 2), E37-E47. http://dx.doi.org/10.3168/jds.S0022-0302(00)74914-9

Beauchemin, K. A., Rode, L. M., Maekawa, M., Morgavi, D. P., \& Kampen, R. (2000). Evaluation of a nonstarchpolysaccharidase feed enzyme in dairy cow diets. J. Dairy Sci., 83, 543-553.

Bernard, J. K., Castro, J. J., Mullis, N. A., Adesogan, A. T., West, J. W., \& Morantes, G. (2010). Effect of feeding alfalfa hay or Tifton 85 bermuda grass haylage with or without a cellulase enzyme on performance of Holstein cows. J. Dairy Sci., 93, 5280-5285. http://dx.doi.org/10.3168/jds.2010-3111

Bowman, G. R., Beauchemin, K. A., \& Shelford, J. A. (2002). The proportion of the diet to which fibrolytic enzymes are added affects nutrient digestion by lactating dairy cows. J. Dairy Sci., 85, 3420-3429. http://dx.doi.org/10.3168/jds.S0022-0302(02)74430-5

Bruno, R. G. S., Rutigliano, H. M., Cerri, R. L., Robinson, P. H., \& Santos, J. E. P. (2009). Effect of feeding Saccharomyces cerevisiae on performance of dairy cows during summer heat stress. Anim. Feed Sci. Technol., 150, 175-186. http://dx.doi.org/10.1016/j.anifeedsci.2008.09.001

Casey, P. G., Gardiner, G. E., Casey, G., Bradshaw, B., Lawlor, P. G., Lynch, P. B., ... Hill, C. (2007). A 5-strain probiotic combination reduces pathogen shedding and alleviates disease signs in pigs challenged with Salmonella enterica Serovar Typhimurium. Applied Environ. Microb., 73, 1858-1863. http://dx.doi.org/10.1128/AEM.01840-06

Chaucheyras-Durand, F., Walker, N. D., \& Bach, A. (2008). Effects of active dry yeasts on the rumen microbial ecosystem: Past, present and future. Anim. Feed Sci. Technol., 145, 5-26. http://dx.doi.org/10.1016/j.anifeedsci.2007.04.019

Crocker, L. M., DePeters, E. J., Fadel, J. G., Perez-Monti, H., Taylor, S. J., Wyckoff, J. A., \& Zinn, R. A. (1998). Influence of processed corn grain in diets of dairy cows on digestion of nutrients and milk composition. $J$. Dairy Sci., 81, 2394-2407. http://dx.doi.org/10.3168/jds.S0022-0302(98)70131-6

Dawson, K. A. (1992). Current and future role of yeast culture in animal production: A review of research over the last six years. Asia Pacific Lecture Tour on "Improving Nutrient Utilization while reducing pollution: New Dimensions Through Biotechnology" (pp.15-37).

Deguchi, Y., Makino, A., Iwabuchi, A., Watanuki, M., \& Yamashita, T. (1993). Selection of ammonia-assimilating bifidobacteria and their effect on ammonia levels in rat cecal contents and blood. Microb. Ecol. Health Dis., 6, 85-94. http://dx.doi.org/10.3109/08910609309141566

El-Ashry, M. A., Fayed, A. M., Youssef, K. M., Salem, F. A., \& Aziz, H. A. (2003). Effect of feeding Flavomycin or yeast as feed supplement on lamb performance in Sinai.Egy. J. Nutri Feeds., 6, 1009-1022. 
Eun, J. S., \& Beauchemin, K. A. (2005). Effects of a proteolytic feed enzyme on intake, digestion, ruminal $\begin{array}{llllll}\text { fermentation, and milk production. J. Dairy } & \text { Sci., }\end{array}$ http://dx.doi.org/10.3168/jds.S0022-0302(05)72890-3

Gado, H. M., Salem, A. Z. M., Robinson, P. H., \& Hassan, M. (2009). Influence of exogenous enzymes on nutrient digestibility, extent of ruminal fermentation as well as milk production and composition in dairy cows. Anim. Feed Sci. Technol., 154, 36-46. http://dx.doi.org/10.1016/j.anifeedsci.2009.07.006

Gourinier-Chateau, N., Larpent, J. P., Castellanos, M. I., \& Larpent, J. L. (1994). Probiotics in animal and human nutrition. Technique et Documentation Lavoisier, Paris (France), Abstr.

Guedes, C. M., Gonçalves, D., Rodrigues, M. A. M., \& Dias-da-Silva, A. (2008). Effects of a Saccharomyces cerevisiae yeast on ruminal fermentation and fibre degradation of maize silages in cows. Anim. Feed Sci. Tech., 145, 27-40. http://dx.doi.org/10.1016/j.anifeedsci.2007.06.037

Higginbotham, G. E, Coller, C. A., Aseltine, M. S., \& Bath, D. L. (1994) Effect of yeast culture and Aspergillusoryzae extract on milk yield in a commercial dairy herd. Journal of Dairy Science, 77, 343-348. http://dx.doi.org/10.3168/jds.S0022-0302(94)76960-5

Holtshausen, L., Chung, Y. H., Gerardo-Cuervo, H., Oba, M., \& Beauchemin, K. A. (2011). Improved milk production efficiency in early lactation dairy cattle with dietary addition of a developmental fibrolytic enzyme additive. J. Dairy Sci., 94, 899-907. http://dx.doi.org/10.3168/jds.2010-3573

Hristov, A. N., McAllister, T. A., \& Cheng, K. J. (2000). Intraruminal supplementation with increasing levels of exogenous polysaccharides-degrading enzymes: Effects on nutrient digestion in cattle fed a barley grain diet. J. Anim. Sci., 78, 477-487.

Ismaiel, A. M., El-Far, A. H., \& Abou-Ganema, I. I. (2010). Effect of Tonilisat and Roemin W2 Supplementations on the Performance of Lambs. Intern. J. Biol. Life Sci., 6(4).

Jouany J. P., \& Morgavi, D. P. (2007). Use of 'natural' products as alternatives to antibiotic feed additives in ruminant production. Animal, 1, 1443-1466. http://dx.doi.org/10.1017/S1751731107000742

Knowlton, K. F., McKinney, J. M., \& Cobb, C. (2002). Effect of a direct-fed fibrolytic enzyme formulation on nutrient intake, partitioning, and excretion in early and late lactation Holstein cows. J. Dairy Sci., 85, 3328-3335. http://dx.doi.org/10.3168/jds.S0022-0302(02)74421-4

Kung, L., Cohen, M. A., Rode, L. M., \& Treacher, R. J. (2002). The effect of fibrolytic enzymes sprayed onto forages and fed in a total mixed ratio to lactating dairy cows. J. Dairy Sci., 85, 2396-2402. http://dx.doi.org/10.3168/jds.S0022-0302 (02)74321-X

McGilliard, M. L., \& Stallings, C. C. (1998). Increase milk yield of commercial dairy herds fed a microbial and enzyme supplement. J. Dairy Sci., 81, 1353-1357. http://dx.doi.org/10.3168/jds.S0022-0302(98)75698-X

Mir, Z., \& Mir, P. S. (1994). Effect of the addition of live yeast (Saccharomyces cerevisiae) on growth and carcass quality of steers fed high-forage or high-grain diets and on feed digestibility and in situ degradability. J. Anim. Sci., 72, 537- 545.

Newbold, C. J., Wallace, R. J., \& McIntosh, F. M. (1996). Mode of action of the yeast Saccharomyces cerevisiae as a feed additive for ruminants. Br. J. Nutr., 76, 249-261. http://dx.doi.org/10.1079/BJN19960029

Nikkhah, A., Bonadaki, M. D., \& Zali, A. (2004). Effects of feeding yeast (Saccharomyces cerevisiae) on productive performance of lactating Holstein dairy cow. Ir. J. Agri. Sci., 35, 53-60.

Nocek, J. E., Kautz, W. P., Leedle, J. A., \& Allman, J. G. (2002). Ruminal supplementation of direct-fed microbials on diurnal $\mathrm{pH}$ variation and in situ digestion in dairy cattle. J. Dairy Sci., 85, 429-433. http://dx.doi.org/10.3168/jds.S0022-0302(02)74091-5

Nocek, J. E., Kautz, W. P., Leedle, J. A., \& Block, E. (2003). Direct-fed microbial supplementation on the performance of dairy cattle during the transition period. J. Dairy Sci., 86, 331-335. http://dx.doi.org/10.3168/jds.S0022-0302(03)73610-8

Piva, G., Belladonna, S., Fusconi, G., \& Siebaldi, F. (1993). Effects of yeast on dairy cows performance, ruminal fermentation, blood components, and milk manufacturing properties. J. Dairy Sci., 76, 2717-2722. http://dx.doi.org/10.3168/jds.S0022-0302(93)77608-0

Preston, T. R. (1995). Biological and for research workers. Rome: FAO, 1995 (Chap. 9, p.191). 
Raeth-Knight, M. L., Linn, J. G., \& Jung, H. (2007). Effect of direct-fed microbials on performance, diet digestibility, and rumen characteristics of Holstein dairy cows. J. Dairy Sci., 90, 1802-1809. http://dx.doi.org/10.3168/jds.2006-643

Samli, H. E., Senkoylu, N., Koc, F., Kanter, M., \& Agma, A. (2007). Effects of enterococcus faecium and dried whey on broiler performance, gut histomorphology and intestinal microbiota. Arch. Anim. Nutr., 61, 42-49. http://dx.doi.org/10.1080/17450390601106655

SAS. (2002). SAS users guide Statistical Analyses Systems Institute (pp. 549-640). Cary, USA.

Steel, R. G. D., \& Torrie, J. H. (1980). Principles and Procedure of Statistics. A Biometrical Approach (2nd ed., pp. 137-269). Mac Graw-Hill Com.

Steinfeld, H., Gerber, P., Wassenaar, T., Castel, V., Rosales, M., \& de Haan, C. (2006). Livestock's Long Shadow: Environmental Issues and Options. Rome: Food and Agriculture Organization of the United Nations.

Sutton, J. D., Phipps, R. H., Beever, D. E., Humphries, D. J., Hartnell, G. F., Vicini, J. L., \& Hard, D. L. (2003). Effect of method of application of a fibrolytic enzyme product on digestive processes and milk production in Holstein-Friesian cows. J. Dairy Sci., 86, 546-556. http://dx.doi.org/10.3168/jds.S0022-0302(03)73633-9

Szasz, J. L., McCalmant, T. M., Hunt, C. W., Grove, A. V., \& Kennington, L. R. (2002). Effect of a fibrolytic enzyme preparation on intake and digestibility of bluegrass seed straw fed to beef cattle. Proc. West. Sec. Am. Soc. Anim., Sci., 53, 313.

Torres-Rodriguez, A., Donoghue, A. M., Donoghue, D. J., Barton, J. T., Tellez G., \& Hargis, B. M. (2007). Performance and condemnation rate analysis of commercial Turkey flocks treated with a Lactobacillus sp.-based probiotic. Poult. Sci., 86, 444-446.

Van Soest, P. J., Robertson, J. B., \& Lewis, B. A. (1991). Methods for dietary fibre, neutral detergent fibre and nonstarch polysaccharides in relation to animal nutrition. J. Dairy Sci., 74, 3583-3597. http://dx.doi.org/10.3168/jds.S0022-0302(91)78551-2

Wallace, R. J., Colombatto, D., \& Robinson, P. H. (2008). Enzymes, direct-fed microbials and plant extracts in ruminant nutrition. Anim. Feed Sci. Tech. 145, 1-4. http://dx.doi.org/10.1016/j.anifeedsci.2007.07.006

Wallace, R. J., Onodera, R., \& Cotta, M. A. (1997). Metabolism of nitrogen-containing compounds. In P. N. Hobson \& C. S. Stewart (Eds.), The Rumen Microbial Ecosystem (2nd ed., pp. 283-328). New York, NY: Blackie Academic and Professional. http://dx.doi.org/10.1007/978-94-009-1453-7_7

Wang, Y., McAllister, T. A., Rode, L. M., Beauchemin, K. A., Morgavi, D. P., Nsereko, V. L., ... Yang, W. (2001). Effects of an exogenous enzyme preparation on microbial protein synthesis, enzyme activity and attachment to feed in the Rumen Simulation Technique (Rusitec). Br. J. Nutr., 85, 325-332. http://dx.doi.org/10.1079/BJN2000277

Ware, R. A., \& Zinn, R .A. (2005). Influence of Maceration and fibrolytic enzyme on the feeding value of rice straw. J. Anim. Vet. Adv., 4, 387-392.

Warner, A. C. I. (1964). Production of volatile fatty acids in the rumen. Methods of measurements. Nutr. Abs. Rev., $34,339$.

Wiedmeier, R. D., Arambel, M. J., \& Walters, J. L. (1987). Effect of yeast culture and Aspergillus oryzae fermentation extract on ruminal characteristics and nutrient digestibility. J. Dairy Sci., 70, 2063-2068. http://dx.doi.org/10.3168/jds.S0022-0302(87)80254-0

Yalçin, S., Yalçin, S., Can, P., Gurdal, A., Bag, C., \& Eltan, O. (2011).The nutritive value of live yeast culture (Saccharomyces cerevisiae) and its effect on milk yield, milk composition and some blood parameters of dairy cows. Asian-Aust. J. Anim. Sci., 24, 1377-1385.

Yang, W. Z., Beauchemin, K. A., \& Rode, L. M. (2000). A comparison of methods of adding fibrolytic enzymes to lactating cow diets. J. Dairy Sci., 83, 2512-2520. http://dx.doi.org/10.3168/jds.S0022-0302(00)75143-5

\section{Copyrights}

Copyright for this article is retained by the author(s), with first publication rights granted to the journal.

This is an open-access article distributed under the terms and conditions of the Creative Commons Attribution license (http://creativecommons.org/licenses/by/3.0/). 